\title{
Environmental Study on Atmospheric Suspended Particulate Matter and Heavy Metals in Sandoub Area, Al-Mansoura, Egypt
}

\author{
Omnya A. El-Batrawy ${ }^{1}$, Maie I. El-Gammal ${ }^{* 1}$, Mohamed A. Attia ${ }^{2}$ \\ ${ }^{1}$ Department of Environmental Sciences- Faculty of Science- Damietta University- Egypt. \\ ${ }^{2}$ Workers University- Egypt.
}

Received: 1 November 2017 /Accepted: 23 December 2017

*Corresponding author: El-Gammal@yahoo.com

\begin{abstract}
Air quality of urban areas has deteriorated as a result of rapid industrialization and increased vehicle emissions. The aim of the study was conducted to evaluate the levels of ambient particles and some heavy metals (lead, zinc, cadmium and manganese) in Sandoub area, Al-Mansoura, Egypt. The main sources of these heavy metals in the sampled area could be attributed to anthropogenic activities like open incineration of waste and vehicular traffic. Lead was the dominated metal at all studied sites. $\mathrm{Pb}$ had been reported to be traffic related as a constituent of leaded gasoline. Mean of PM10 and heavy metals were higher than the ambient air quality limits recommended by EEAA. Therefore efforts should be taken to control the atmospheric pollution from hazardous toxic effects on the environment and human health. So far, the data generated in the study will be helpful for proper planning and management in this area as well as other part of the country.
\end{abstract}

Keywords : Air Quality; $\mathrm{PM}_{10}$; Heavy Metals; Pollution sources; open burning.

\section{Introduction}

In recent years, anthropogenic activities including industrial discharges, vehicle emissions and other activities critically affected the atmospheric environment. The ambient air quality has deteriorated to such an extent that it adversely affects the health and welfare of human beings (Das et al., 2015). $\mathrm{PM}_{10}$ are more likely to increase the frequency of respiratory and cardiovascular diseases (Padoan et al., 2016).

North Africa is one of the world's major dust-emitting regions. Consequently, a wide range of nature and emission sources contribute to particulate matter concentrations in the atmosphere (El-Fadel and Massoud, 2000). The major anthropogenic air pollution sources in African cities include industrial activities, emissions from waste and biomass burning for household and commercial needs, and emissions from vehicles as well as suspension from unpaved roads (Engelstaedtera et al., 2006).

Heavy metals are one of the most important pollutants emitted to the atmosphere due to their toxic effects on the environment and human health (Fang et al., 2015). Heavy metals 
may come from many different sources in urbanized areas, including vehicle emissions, industrial discharges and other activities (Talebi and Abedi, 2004).

Sandoub is considered as one of the major industrial areas in Mansoura. Industrial activities, heavy traffic missions and biomass burning are considered to be the major pollution sources in Sandoub. The aim of this study is to evaluate the levels of ambient particles and some heavy metals; lead $(\mathrm{Pb})$, Zinc $(\mathrm{Zn})$, Cadmium (Cd) and Manganese (Mn) in Sandoub area, AlMansoura, Egypt.

\section{Material and Methods}

\section{Study area}

Sandoub is located at the south of AlMansoura city, the capital of Al-Dakhlia Governorate, Egypt. It extends between $31^{\circ} 01^{\prime} 15$ " $\mathrm{N}$ and $31^{\circ} 38^{\prime} 8^{\prime \prime} \mathrm{E}$ (Fig 1). Sandoub area hosts many industries namely; Al-Mansoura for resin and chemical industries Company; Al-Dakhlia spin and wear Company; Soap, oil and animal fodder industry; and Al-Dakhlia treatment and disposal project (the open burning of Garbage).Location of the six sampling sites in Sandoub area is presented in Table 1 and Fig. 2.

Table (1): Location of the six sampling sites in Sandoub area.

\begin{tabular}{c|l}
\hline Site & \multicolumn{1}{|c}{ Location } \\
\hline Site 1 & $\begin{array}{l}\text { behind Al-Mansoura for resin and chemicall } \\
\text { industries Company and is surrounded by low } \\
\text { residential area }\end{array}$ \\
\hline Site 2 & $\begin{array}{l}\text { beside the sub gate of Al-Mansoura for resin and } \\
\text { chemical industrial Company along the highway } \\
\text { of Al-Mansoura and Mit-Ghamr }\end{array}$ \\
\hline Site 3 & $\begin{array}{l}\text { beside the primary gate of El-Mansoura for } \\
\text { resins and Chemical Industries Company along } \\
\text { the main road between Al-Mansoura and El- } \\
\text { Sinballaween }\end{array}$ \\
\hline Site 4 & $\begin{array}{l}\text { beside the primary Gate of Al-Dakhlia spin and } \\
\text { wear Company along the highway between El- } \\
\text { Mansoura and El-Sinballaween }\end{array}$ \\
\hline Site 5 & $\begin{array}{l}\text { beside the primary Gate of Soap, oil and animal } \\
\text { fodder industry along the highway between Al- } \\
\text { Mansoura and El-Sinballaween. It is surrounded } \\
\text { with Shawa residential area. }\end{array}$ \\
\hline Site 6 & $\begin{array}{l}\text { beside Al-Dakahlia treatment and disposal } \\
\text { project. It is surrounded by agriculture and low } \\
\text { residential areas. }\end{array}$ \\
\hline
\end{tabular}

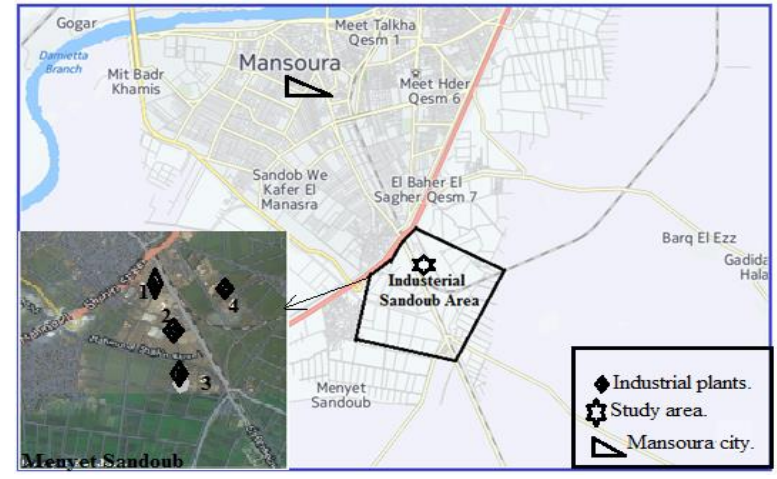

Fig (1): Location of Sandoub area, El-Mansoura, Egypt.

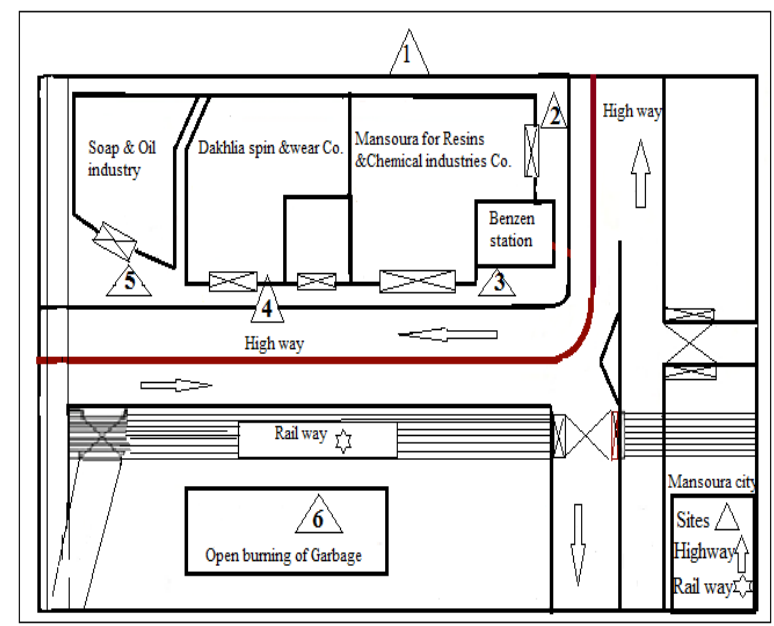

Fig (2): Location of the six sampling sites in Sandoub area.

\section{Sampling Protocol}

Sampling of $\mathrm{PM}_{10}$ was carried out simultaneously at the six sites twice a month from January to December 2015. Sampling was carried out for $8 \mathrm{hrs}$ with a mean flow rate of 1.5 $1 / \mathrm{min}$. The sampling equipment was located on a building at about $5 \mathrm{~m}$ from the ground. Particles were collected on Whatman $47 \mathrm{~mm}$ membrane filters with $0.45 \mu \mathrm{m}$ pores size. Filters were weighed in temperature and relative humidity control. $\mathrm{PM}_{10}$ concentrations were measured using the filtration method (Harrison and Perry, 1986).A definite section of the filter on which suspended particles were accumulated was cut and digested in $3 \mathrm{M}$ nitric acid. The concentration of some metals including $\mathrm{Pb}, \mathrm{Zn}, \mathrm{Cd}$ and $\mathrm{Mn}$ were measured following well-established techniques (Lodge and Editor, 1998) using flame atomic absorption spectrophotometer.

\section{Statistical Analysis}

The descriptive statistics (means, minima and maxima) were used. In addition, the 
relationship among heavy metals in water was assessed using Pearson's correlation coefficient. All statistical analyses were done using the computer program of Minitab program, version 16.1 .

\section{Results and Discussion}

Summary statistics of particulate matter $\left(\mathrm{PM}_{10}\right)$ and heavy metal; $\mathrm{Pb}, \mathrm{Zn}, \mathrm{Cd}$ and $\mathrm{Mn}$ concentrations in the six sampling sites of Sandoub area during the study period from January to December 2015are presented in Table (1).

\section{PM10 in the Atmosphere of Sandoub Area}

The monthly mean concentrations of particulate matter $\left(\mathrm{PM}_{10}\right)$ as $\mathrm{mg} / \mathrm{m}^{3}$ in Sandoub area from January to December 2015 are represented in Fig (3). The results show that the mean concentration of $\mathrm{PM}_{10}$ varied at site 1 from $122 \mu \mathrm{g} / \mathrm{m}^{3}$ in December to $7.89 \mu \mathrm{g} / \mathrm{m}^{3}$ in April and at site 6 from $1.27 \mu \mathrm{g} / \mathrm{m}^{3}$ in July to $4.78 \mu \mathrm{g} / \mathrm{m}^{3}$ in October; comparing with the sites $2,3,4$ and 5 the mean concentration ranges were (1.41-5.17), (1.17-4.99), (1.44 - 5.56) and (1.25 - 4.79) $\mu \mathrm{g} / \mathrm{m}^{3}$ in (June - October), respectively (Table 2). The annual mean concentrations of particulate matter $\left(\mathrm{PM}_{10}\right)$ in Sandoub area were exceeded the annual permissible limit $\left(125 \mu \mathrm{g} / \mathrm{m}^{3}\right)$ established by the Egyptain Environmental Affairs Agency (EEAA, 1995). Large numbers of vehicles, as well as a substantial concentration of industrial facilities, contribute to high levels of $\mathrm{PM}_{10}$. In addition to industrial and mobile sources, open waste burning contributed substantially to particulate matter pollution levels, particularly during the winter months.

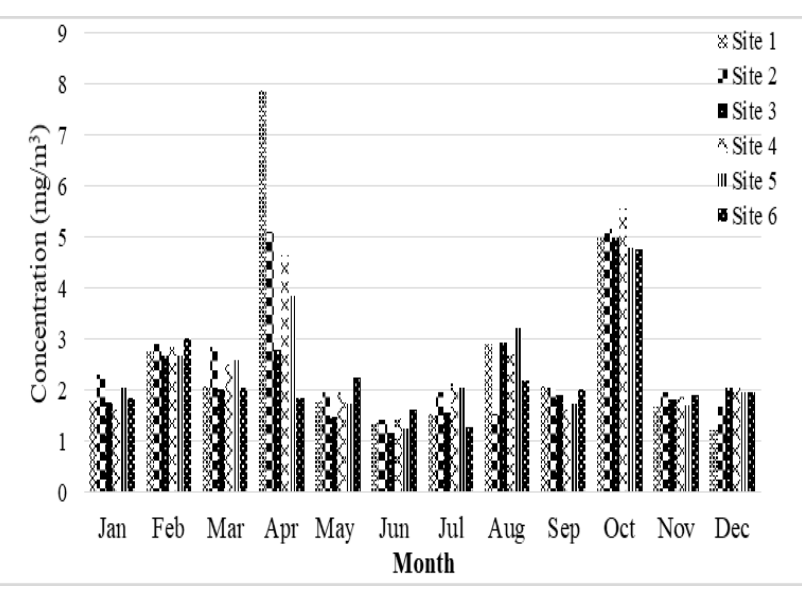

Fig (3): Concentrations of $\mathrm{PM}_{10}$ in the air of Sandoub area.

\section{Heavy Metals in the Atmosphere of Sandoub Area}

The monthly mean concentrations of heavy metals as $\mu \mathrm{g} / \mathrm{m}^{3}$ in Sandoub area are represented in Fig (4). It is noticed that $\mathrm{Pb}$ varied at site 1 from $1.01 \mu \mathrm{g} / \mathrm{m}^{3}$ in Novembe rto 4.0 $\mu \mathrm{g} / \mathrm{m}^{3}$ in June, at site 2 from $1.0 \mu \mathrm{g} / \mathrm{m}^{3}$ in November to $3.77 \mu \mathrm{g} / \mathrm{m}^{3}$ in May, at site 3 from $1.87 \mu \mathrm{g} / \mathrm{m}^{3}$ in January to $3.99 \mu \mathrm{g} / \mathrm{m}^{3}$ in September, at site 4 from $1.07 \mu \mathrm{g} / \mathrm{m}^{3}$ in October to $4.42 \mu \mathrm{g} / \mathrm{m}^{3}$ in June, at site 5 from $1.10 \mu \mathrm{g} / \mathrm{m}^{3}$ in February to $3.71 \mu \mathrm{g} / \mathrm{m}^{3}$ in June, and at site 6 from $1.01 \mu \mathrm{g} / \mathrm{m}^{3}$ in August to $2.73 \mu \mathrm{g} / \mathrm{m}^{3}$ in May (Table 2 and Fig 4a). The annual mean concentrations of $\mathrm{Pb}$ in Sandoub area were exceeded the annual permissible limit (1.0 $\mu \mathrm{g} / \mathrm{m}^{3}$ ) recommended by the Egyptain Environmental Affairs Agency (EEAA, 1995). The high pollution of $\mathrm{Pb}$ metal may be associated with heavy traffic intensity (Oil leakage from car and vehicle exhaust).

Table (2): The summary statistics of particulate matter $\left(\mathrm{PM}_{10}\right)$ and heavy metals in Sandoub area

\begin{tabular}{|c|c|c|c|c|c|c|c|}
\hline & & \multicolumn{6}{|c|}{ Concentration * } \\
\hline & & Site 1 & Site 2 & Site 3 & Site 4 & Site 5 & Site 6 \\
\hline \multirow{2}{*}{$\mathbf{P M}_{10}$} & Mean & 2.68 & 2.57 & 2.26 & 2.59 & 2.47 & 2.23 \\
\hline & Range & $1.22-7.89$ & $1.41-5.17$ & $1.17-4.99$ & $1.44-5.56$ & $1.25-4.79$ & $1.27-4.78$ \\
\hline \multirow{2}{*}{$\mathbf{P b}$} & Mean & 2.17 & 2.39 & 2.72 & 2.4 & 2.45 & 1.63 \\
\hline & Range & $1.01-4$ & $1-3.77$ & $1.87-3.99$ & $1.07-4.42$ & $1.1-3.71$ & $1.01-2.73$ \\
\hline \multirow{2}{*}{ Zn } & Mean & 0.54 & 0.6 & 1.92 & 1.14 & 0.9 & 0.83 \\
\hline & Range & $0.1-1.01$ & $0.01-1.41$ & $0.12-3.04$ & $0.1-3.01$ & $0.13-2.12$ & $0.09-1.91$ \\
\hline \multirow{2}{*}{ Cd } & Mean & 0.91 & 0.85 & 1.24 & 1.36 & 1.64 & 1.17 \\
\hline & Range & $0.001-1.79$ & $0.001-1.93$ & $0.36-1.89$ & $0.86-2.23$ & $0.96-2.36$ & $0.01-2.64$ \\
\hline \multirow{2}{*}{ Mn } & Mean & 0.69 & 0.73 & 0.49 & 0.93 & 0.72 & 0.69 \\
\hline & Range & $0.1-2.31$ & 0.16- 2.17 & $0.05-1.04$ & $0.13-2.42$ & $0.09-1.65$ & $0.13-0.99$ \\
\hline
\end{tabular}

$* \mathrm{PM}_{10}$ values are in $\mathrm{mg} / \mathrm{m}^{3}$; heavy metals values are expressed in $\mu \mathrm{g} / \mathrm{m}^{3}$ 
(a) $\mathrm{Pb}$

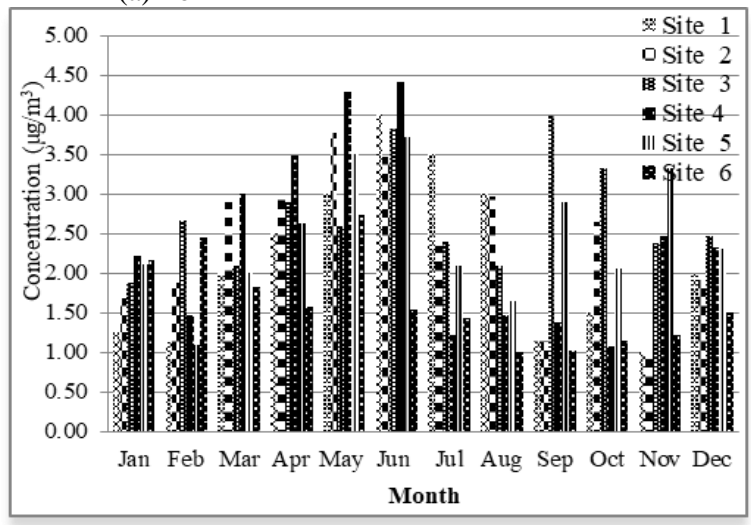

(b) $\mathrm{Zn}$

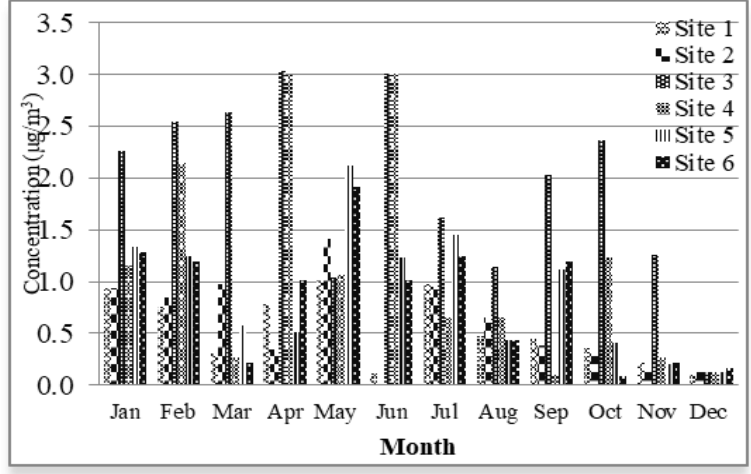

(c) $\mathrm{Cd}$

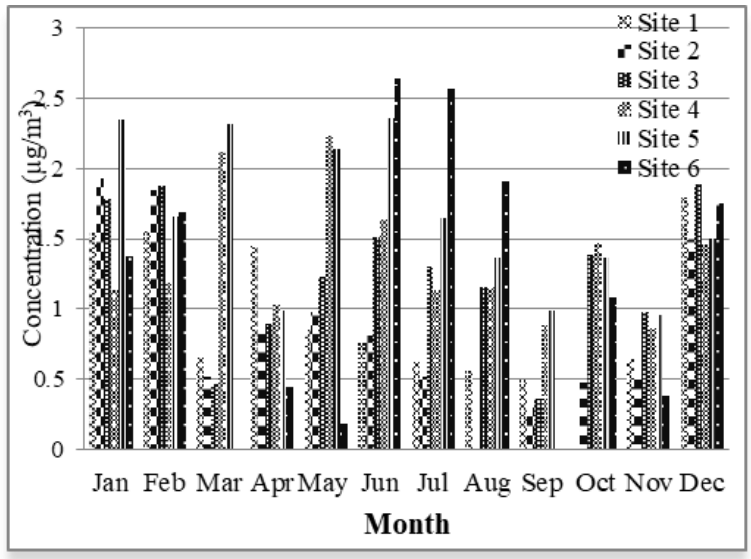

(d) $\mathrm{Mn}$

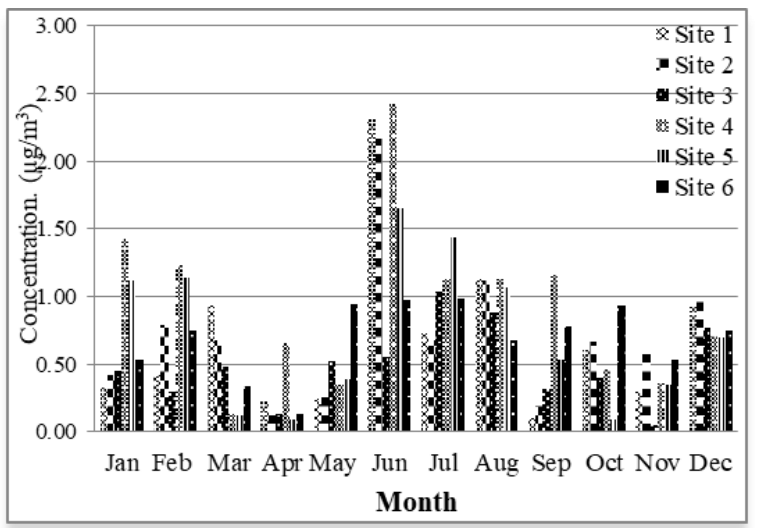

Fig (4): Concentrations of heavy metals; (a) $\mathrm{Pb}$, (b) Zn, (c) $\mathrm{Cd}$ and (d) Mn, in the air of Sandoub area.
It is noticed that $\mathrm{Zn}$ varied at site 1 from $0.1 \mu \mathrm{g} / \mathrm{m}^{3}$ in December to $1.01 \mu \mathrm{g} / \mathrm{m}^{3}$ in May, at site 2 from $0.01 \mu \mathrm{g} / \mathrm{m}^{3}$ in June to $1.41 \mu \mathrm{g} / \mathrm{m}^{3}$ in May, at site 3 from $0.12 \mu \mathrm{g} / \mathrm{m}^{3}$ in December to $3.04 \mu \mathrm{g} / \mathrm{m}^{3}$ in April, at site 4 from $0.1 \mu \mathrm{g} / \mathrm{m}^{3}$ in September to $3.01 \mu \mathrm{g} / \mathrm{m}^{3}$ in June, at site 5 from0.13 $\mu \mathrm{g} / \mathrm{m}^{3}$ in December to $2.12 \mu \mathrm{g} / \mathrm{m}^{3}$ in May, and at site 6 from $0.09 \mu \mathrm{g} / \mathrm{m}^{3}$ in October to $1.9 \mu \mathrm{g} / \mathrm{m}^{3}$ in April(Table 2 and Fig $5 \mathrm{~b}$ ).

It is noticed that $\mathrm{Cd}$ varied at site 1 from $0.001 \mu \mathrm{g} / \mathrm{m}^{3}$ in October to $1.79 \mu \mathrm{g} / \mathrm{m}^{3}$ in December, at site 2 from $0.001 \mu \mathrm{g} / \mathrm{m}^{3}$ in August to $1.93 \mu \mathrm{g} / \mathrm{m}^{3}$ in January, at site 3 from 0.36 $\mu \mathrm{g} / \mathrm{m}^{3}$ in September to $1.89 \mu \mathrm{g} / \mathrm{m}^{3}$ in December, at site 4 from $0.86 \mu \mathrm{g} / \mathrm{m}^{3}$ in November to 2.23 $\mu \mathrm{g} / \mathrm{m}^{3}$ in May, at site 5 from0.096 $\mu \mathrm{g} / \mathrm{m}^{3}$ in November to $2.36 \mu \mathrm{g} / \mathrm{m}^{3}$ in June, and at site 6 from0.01 $\mu \mathrm{g} / \mathrm{m}^{3}$ in both March and September to $2.64 \mu \mathrm{g} / \mathrm{m}^{3}$ in June (Table 2 and Fig 5c).

Also, $\mathrm{Mn}$ varied at site 1 from $0.1 \mu \mathrm{g} / \mathrm{m}^{3}$ in September to $2.31 \mu \mathrm{g} / \mathrm{m}^{3}$ in June, at site 2 from $0.16 \mu \mathrm{g} / \mathrm{m}^{3}$ in April to $2.17 \mu \mathrm{g} / \mathrm{m}^{3}$ in June, at site 3 from $0.05 \mu \mathrm{g} / \mathrm{m}^{3}$ in November to $1.04 \mu \mathrm{g} / \mathrm{m}^{3}$ in July, at site 4 from $0.13 \mu \mathrm{g} / \mathrm{m}^{3}$ in March to 2.42 $\mu \mathrm{g} / \mathrm{m}^{3}$ in June, at site 5 from $0.09 \mu \mathrm{g} / \mathrm{m}^{3}$ in October to $1.65 \mu \mathrm{g} / \mathrm{m}^{3}$ in June, and at site 6 from 0.13 in April to $0.99 \mu \mathrm{g} / \mathrm{m}^{3}$ in July (Table 2 and Fig 5d).

\section{Distribution of PM10 and Heavy Metals in the air of Sandoub Area}

Percentage contribution of each site to $\mathrm{PM}_{10}$ in Sandoub areacan be arranged according to the order: site $1=$ site $4>$ site $2=$ site $5>$ site $3=$ site 6 (Fig 5). It was noticed that all sites have source apportionment ranged from $15 \%$ to $18 \%$ suggesting influence of the same type/strength emission sources in Sandoub area. Anthropogenic sources of $\mathrm{PM}_{10}$ include transportation, industry, fires, mechanical sources (Salam et al., 2008). 


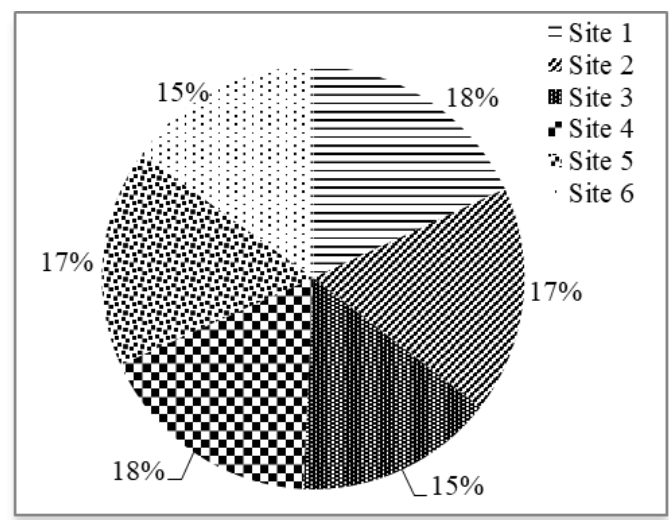

Fig (5): Percentage contribution of each site to $\mathrm{PM}_{10}$ in Sandoub area.

Percentage contributions of each site to heavy metals in Sandoub area were presented in Fig (6). Percentage contribution of each site to $\mathrm{Pb}$ in Sandoub areacan be arranged according to the order: site $3>$ site $5>$ site $4=$ site $2>$ site $1>$ site 6 (Fig 6a). It was noticed that all sites have source apportionment ranged from $12 \%$ to $20 \%$. The Percentage contribution of site 3 was $20 \%$ of the total concentration from the Sandoub area as it is located along the highway adjecent to oil station. $\mathrm{Pb}$ used to be one of the trace elements considered as a marker of vehicle traffic (Cheng et al., 2014).

Percentage contribution of each site to $\mathrm{Zn}$ metal in Sandoub areacan be arranged according to the order: site $3>$ site $4>$ site $5>$ site $6>$ site $2>$ site 1(Fig 6b). All sites have source apportionment ranged from $9 \%$ to $19 \%$ except site $3(33 \%)$. site 3 is subjected to heavy traffic intensity along the year.Zinc may come from lubricating oil and tire of motor vehical (Awan et al., 2013). Concentration of $\mathrm{Zn}$ metal in the atmospheric particulate matter was very high enrichment by the anthropogenic activities (Shah et al., 2012).

Percentage contribution of each site to $\mathrm{Cd}$ in Sandoub areacan be arranged according to the order: site $5>$ site $4>$ site $3>$ site $6>$ site $1>$ site 2(Fig 6c). It was noticed that allsites have source apportioment ranged from $12 \%$ to $23 \%$. This may indicate that Sandoub area was polluted with $\mathrm{Cd}$. Industrial processes, high number of vehicles and combustion sources are the main sources for Cd (Pal et al., 2014).

Percentage contribution of each site to $\mathrm{Mn}$ in Sandoub areacan be arranged according to the order: site $4>$ site $5=$ site $2>$ site $6=$ site $1>$ site 3(Fig 6d). It was noticed that allsites have source apportioment ranged from $12 \%$ to $22 \%$. This may indicate that Sandoub area was polluted with Mn.This may be as a result of anthropogenic activities around the sites that result in high temperature combustion of manganese rich-fuel enhancers or open burning of wastes and industrial processes. Mn also related to industrial processes and brake-drum abrasion (López et al., 2005).
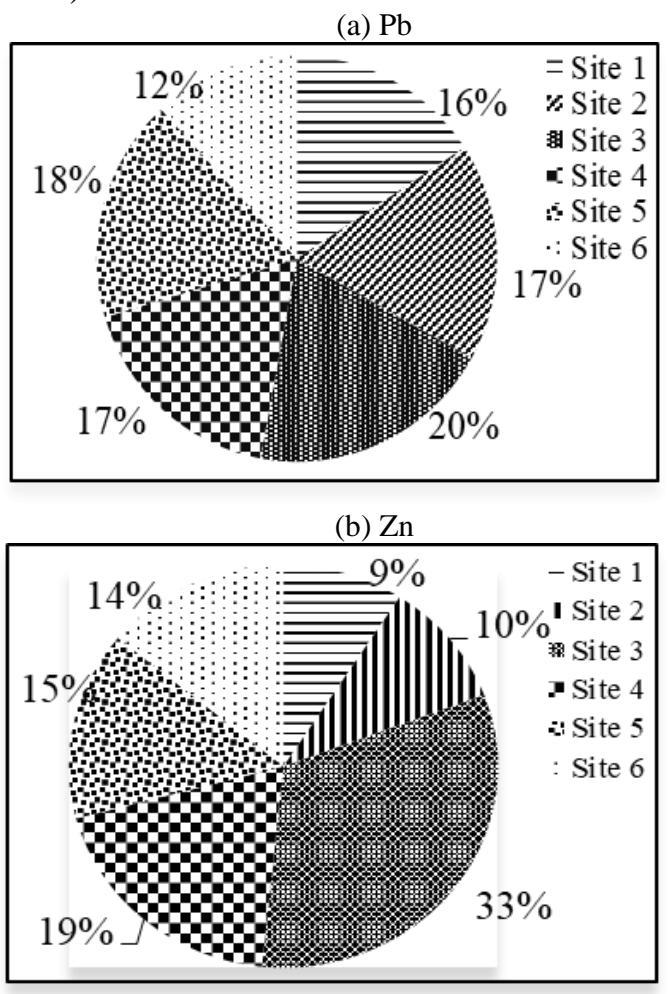

(c) $\mathrm{Cd}$

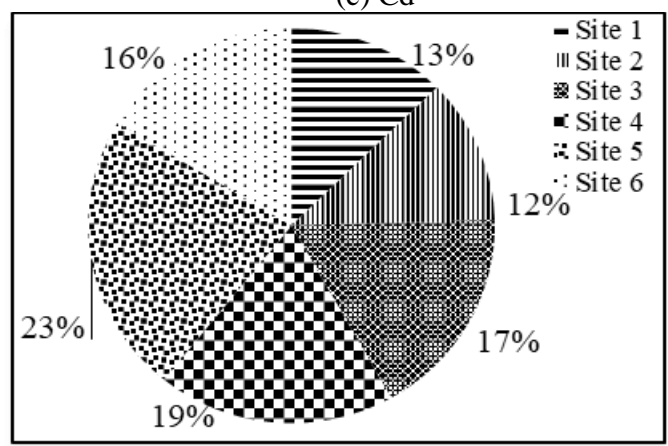

(d) $\mathrm{Mn}$

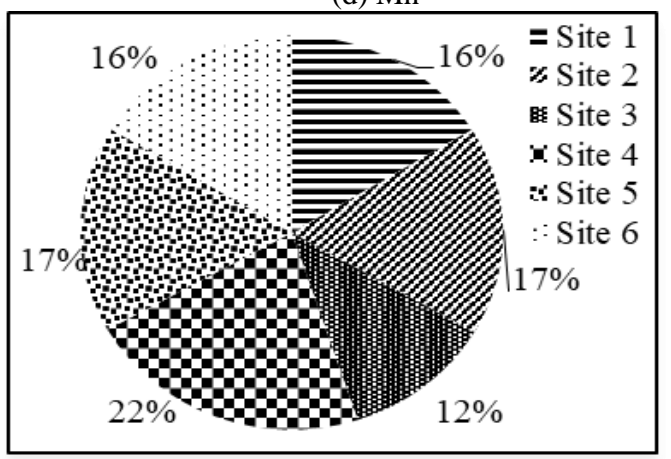

Fig (6): Percentage contribution of each site to heavy metals; (a) $\mathrm{Pb}$, (b) $\mathrm{Zn}$, (c) $\mathrm{Cd}$ and (d) $\mathrm{Mn}$, in Sandoub area. 
(a) Site 1

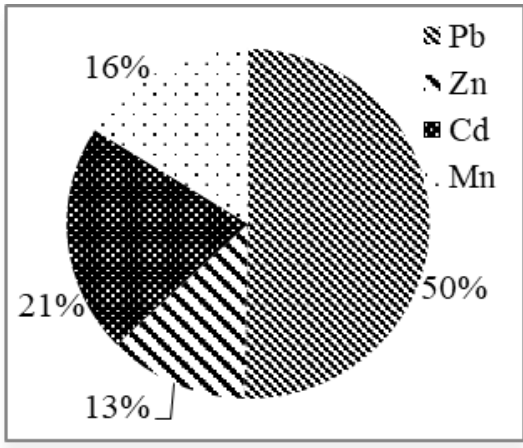

(d) Site 4

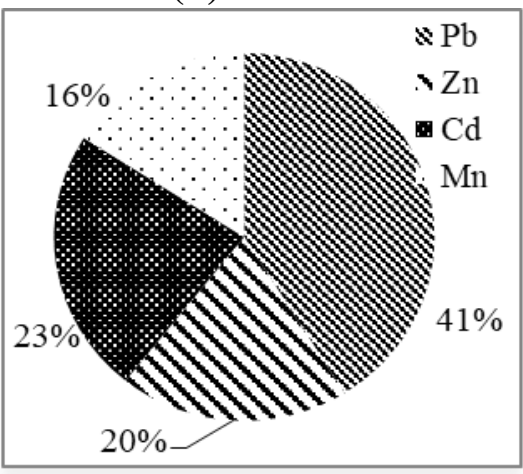

(b) Site 2

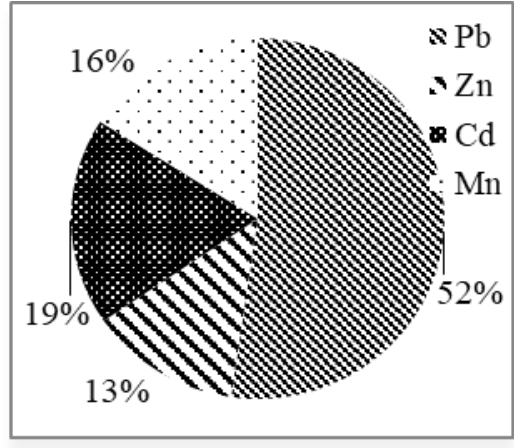

(e) Site 5

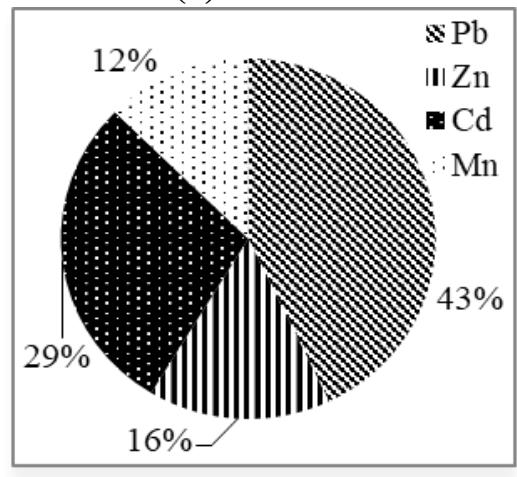

(c) Site 3

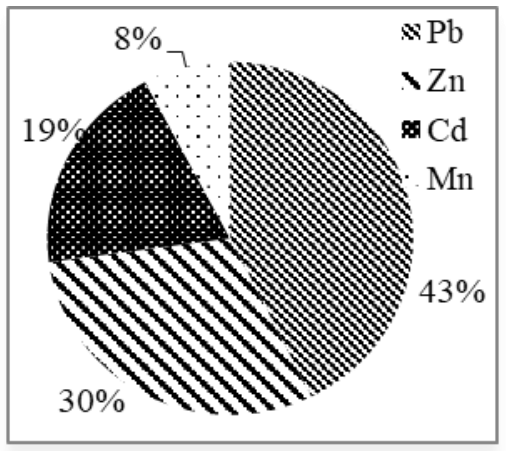

(f) Site 6

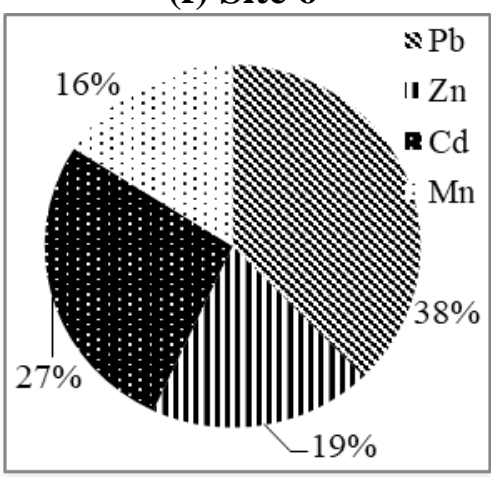

Fig (7): Percentage contribution of $\mathrm{Pb}, \mathrm{Zn}, \mathrm{Cd}$ and $\mathrm{Mn}$ for each site in Sandoub area during 2015.

Percentage contribution of $\mathrm{Pb}, \mathrm{Zn}, \mathrm{Cd}$ and $\mathrm{Mn}$ for each site in Sandoub area during 2015 was represented at Fig (7). Heavy metals can be arranged according to the order: $\mathrm{Pb}(50 \%)$ $\square \mathrm{Cd} \square \mathrm{Mn} \square \mathrm{Zn}$; Pb (52\%) $\square \mathrm{Cd} \square \mathrm{Mn} \square \mathrm{Zn}$; $\mathrm{Pb}(43 \%) \square \mathrm{Zn} \square \mathrm{Cd} \square \mathrm{Mn} ; \mathrm{Pb}(41 \%) \square \mathrm{Cd}$ $\square \mathrm{Zn} \square \mathrm{Mn} ; \mathrm{Pb}(43 \%) \square \mathrm{Cd} \square \mathrm{Zn} \square \mathrm{Mn}$ and $\mathrm{Pb}$ (38\%) $\square \mathrm{Cd} \square \mathrm{Zn} \square \mathrm{Mn}$ at site 1, site 2, site 3, site 4 , site 5 and site 6 , respectively.

It is clear that lead was the dominated metal at all sites in sandoub area. $\mathrm{Pb}$ has been reported to be traffic related as constituents of leaded gasoline (Weckwerth, 2001). It might be due to oil leakages from cars, vehicular exhaust (USEPA, 2012).Cd was the second metal for all sites except for site 3. Possible sources of $\mathrm{Cd}$ include burning of municipal wastes containing discarded Ni-Cd batteries and plastics containing $\mathrm{Cd}$ pigments; vehicular emissions including tyre abrasions (Awan et al., 2011). Zn was the second metal at site 3 . The occurrences of Zn imply that the particulates originate from weathering of a unique form of local geological materials due to wind erosion, construction work, traffic related and residential activities. Besides, $\mathrm{Zn}$ could be released from tires due to the friction and heating (Ramadan et al., 2000).

\section{Evaluation of Air Quality in Sandoub Area}

The annual concentrations of $\mathrm{PM}_{10}$ and heavy metals $(\mathrm{Pb}, \mathrm{Zn}, \mathrm{Cd}$ and $\mathrm{Mn})$ as in the six sampling sites of Sandoub area during 2015are presented in Fig (8). It was concluded that site 1 has the highest value of $\mathrm{PM}_{10}\left(2677.75 \mu \mathrm{g} / \mathrm{m}^{3}\right)$ (table 2). The high pollution of $\mathrm{PM}_{10}$ may be associated with high traffic intensity and industrial emissions. The traffic density was significantly correlated with $\mathrm{PM}_{10}$ (Mao et al. 2009).

Also, it was concluded that site 3 has the highest values of $\mathrm{Pb}\left(2.72 \mu \mathrm{g} / \mathrm{m}^{3}\right)$ and $\mathrm{Zn}(1.92$ $\left.\mu \mathrm{g} / \mathrm{m}^{3}\right)$. Site 3 is located adjacent to oil station along high way road suggesting contribution primarily from traffic emissions and road dust. Vehicle emissions, industrial processes and road dust are the major source-types affecting the local atmosphere (Voutsa et al., 2002). Moreover, site 4 has the highest value of $\mathrm{Mn}\left(0.93 \mu \mathrm{g} / \mathrm{m}^{3}\right)$ and site 5 has the highest value of $\mathrm{Cd}\left(1.64 \mu \mathrm{g} / \mathrm{m}^{3}\right)$. Vehicular traffic contributes to $\mathrm{Cd}, \mathrm{Pb}$ and $\mathrm{Zn}$ while fossil fuel combustion contributes to $\mathrm{Pb}$ and $\mathrm{Cd}$ (Estrellanand lino 2010). 


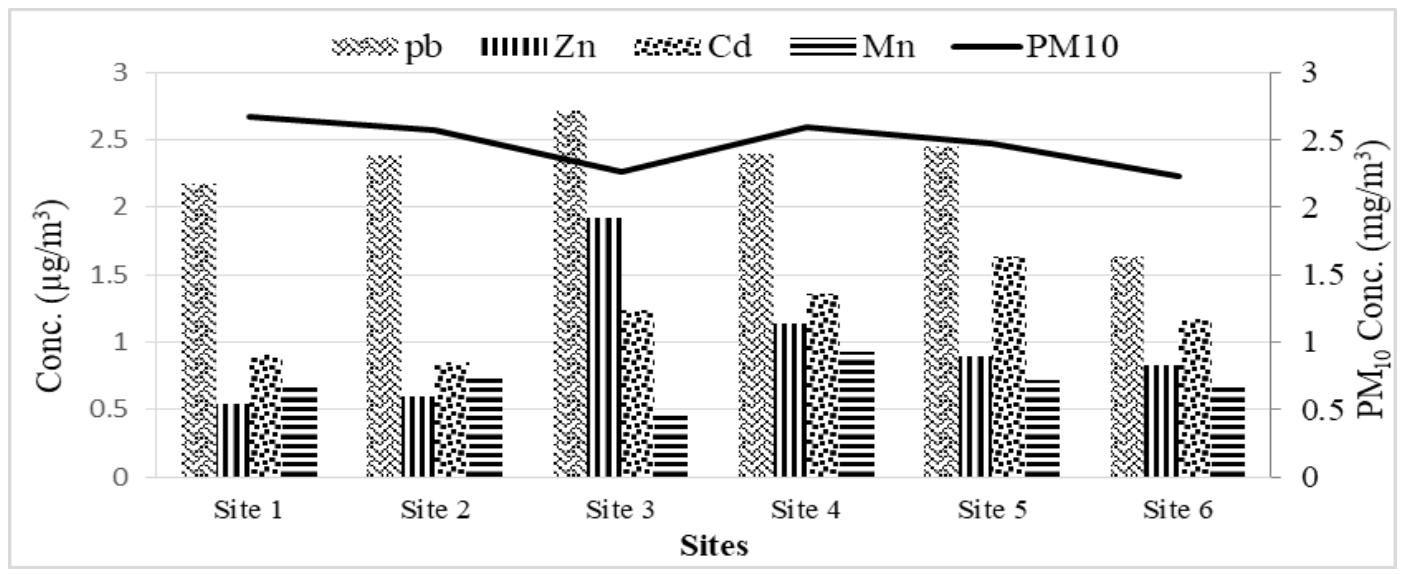

Fig (8): Annual concentrations of $\mathrm{PM}_{10}$ and heavy metals in the air of Sandoub area during 2015.

Table (3): Comparison of of $\mathrm{PM}_{10}$ and heavy metals in Sandoub area with other industrial areas.

\begin{tabular}{|c|c|c|c|c|c|c|}
\hline Location & $\mathbf{P M}_{10}$ & $\mathbf{P b}$ & $\mathbf{Z n}$ & $\mathbf{C d}$ & Mn & References \\
\hline Sandoub & $2.47 \mathrm{mg} / \mathrm{m}^{3}$ & $2.3 \mu \mathrm{g} / \mathrm{m}^{3}$ & $0.99 \mu \mathrm{g} / \mathrm{m}^{3}$ & $1.2 \mu \mathrm{g} / \mathrm{m}^{3}$ & $0.71 \mu \mathrm{g} / \mathrm{m}^{3}$ & Present Study \\
\hline Istanbul & & $\begin{array}{l}3-430 \\
\mathrm{ng} / \mathrm{m}^{3}\end{array}$ & $\begin{array}{l}80-429 \\
\mathrm{ng} / \mathrm{m}^{3}\end{array}$ & $\begin{array}{l}0.31-36 \\
\mathrm{ng} / \mathrm{m}^{3}\end{array}$ & $\begin{array}{l}12.4-53 \\
\mathrm{ng} / \mathrm{m}^{3}\end{array}$ & Ercan and Dinçer (2016) \\
\hline India & $74.7 \mu \mathrm{g} / \mathrm{m}^{3}$ & $23.0 \mathrm{ng} / \mathrm{m}^{3}$ & $927.5 \mathrm{ng} / \mathrm{m}^{3}$ & $1.9 \mathrm{ng} / \mathrm{m}^{3}$ & $18.2 \mathrm{ng} / \mathrm{m}^{3}$ & Police et al. (2016) \\
\hline Iran & $124.6 \mu \mathrm{g} / \mathrm{m}^{3}$ & $0.02 \mu \mathrm{g} / \mathrm{m}^{3}$ & $0.28 \mu \mathrm{g} / \mathrm{m}^{3}$ & - & - & Mobarakeh et al. (2015) \\
\hline Egypt & $300 \mu \mathrm{g} / \mathrm{m}^{3}$ & $0.67 \mu \mathrm{g} / \mathrm{m}^{3}$ & - & - & - & Lowenthal et al. (2014) \\
\hline India & $204 \mu \mathrm{g} / \mathrm{m}^{3}$ & $2.1 \mu \mathrm{g} / \mathrm{m}^{3}$ & $21.24 \mu \mathrm{g} / \mathrm{m}^{3}$ & $0.4 \mu \mathrm{g} / \mathrm{m}^{3}$ & - & Pal et al. (2014) \\
\hline India & $251 \mu \mathrm{g} / \mathrm{m}^{3}$ & - & $4.02 \mu \mathrm{g} / \mathrm{m}^{3}$ & - & - & Gajghate et al. (2012) \\
\hline Egypt & $170 \mu \mathrm{g} / \mathrm{m}^{3}$ & - & - & - & - & Zakey et al. (2008) \\
\hline Bangladesh & $75.5 \mu \mathrm{g} / \mathrm{m}^{3}$ & $0.204 \mu \mathrm{g} / \mathrm{m}^{3}$ & $381 \mathrm{ng} / \mathrm{m}^{3}$ & $13 \mathrm{ng} / \mathrm{m}^{3}$ & - & Salam et al. (2008) \\
\hline Egypt & $360 \mu \mathrm{g} / \mathrm{m}^{3}$ & $7 \mu \mathrm{g} / \mathrm{m}^{3}$ & - & - & - & $\begin{array}{l}\text { Abu-Allaban et al. } \\
\text { (2007) }\end{array}$ \\
\hline Brazil & $87 \mu \mathrm{g} / \mathrm{m}^{3}$ & $101 \mathrm{ng} / \mathrm{m}^{3}$ & $2120 \mathrm{ng} / \mathrm{m}^{3}$ & $0.9 \mathrm{ng} / \mathrm{m}^{3}$ & $\begin{array}{l}1216 \\
\mathrm{ng} / \mathrm{m}^{3}\end{array}$ & Quiterio et al. (2004) \\
\hline Greece & $89 \mu \mathrm{g} / \mathrm{m}^{3}$ & $71 \mathrm{ng} / \mathrm{m}^{3}$ & $215 \mathrm{ng} / \mathrm{m}^{3}$ & $0.70 \mathrm{ng} / \mathrm{m}^{3}$ & $26 \mathrm{ng} / \mathrm{m}^{3}$ & Voutsa et al. (2002) \\
\hline Egypt & $300 \mu \mathrm{g} / \mathrm{m}^{3}$ & $3.2 \mu \mathrm{g} / \mathrm{m}^{3}$ & 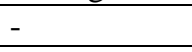 & & - & Nasralla (2001) \\
\hline
\end{tabular}

(Nasralla, 2001; Abu-Allaban et al., 2007; Zakey et al., 2008 and Lowenthal et al., 2014). On the other hand, the present study revealed higher values than that previously recorded worldwide. The comparison between values of heavy metals of air of Sandoub area of the present study with those results of the previous studies is presented in Table (3).

Pearson's correlation coefficients of heavy metals in $\mathrm{PM}_{10}$ of Sandoub area are shown in Table 4. All the metal pairs showed positive relations except for $\mathrm{Mn}-\mathrm{Pb}$ and $\mathrm{Mn}-\mathrm{Zn}$ pairs. $\mathrm{Pb}$ is significantly positively correlated with $\mathrm{Zn}$ $\left(\mathrm{R}^{2}=0.560\right)$, which may suggest a common origin, such as heavily traffic. While $\mathrm{Cd}$ showed relatively weak positive correlations with $\mathrm{Zn}, \mathrm{Pb}$ and $\mathrm{Mn}$ varying from 0.397 to 0.147 . The source for heavy metals may be industrial activities in
Table (4): Pearson's correlation coefficients of heavy metals in $\mathrm{PM}_{10}$ of Sandoub area.

\begin{tabular}{l|l|l|l|l}
\hline & $\mathbf{P b}$ & $\mathbf{Z n}$ & $\mathbf{C d}$ & $\mathbf{M n}$ \\
\hline $\mathbf{P b}$ & 1 & & & \\
\hline $\mathbf{Z n}$ & 0.560 & 1 & & \\
\hline $\mathbf{C d}$ & 0.231 & 0.397 & 1 & \\
\hline $\mathbf{M n}$ & -0.198 & -0.475 & 0.147 & 1 \\
\hline
\end{tabular}

\section{Conclusion}

Ambient air of Sandoub area is contaminated with $\mathrm{PM}_{10}$ and heavy metals. Mean concentration of $\mathrm{PM}_{10}$ and heavy metals ranged from $2.23-2.68 \mathrm{mg} / \mathrm{m}^{3}$ for $\mathrm{PM}_{10}, 1.63-2.72 \mu \mathrm{g} / \mathrm{m}^{3}$ for lead, $0.54-192 \mu \mathrm{g} / \mathrm{m}^{3}$ for Zinc, $0.85-1.64$ $\mu \mathrm{g} / \mathrm{m}^{3}$ for Cadmium and $0.49-0.93 \mu \mathrm{g} / \mathrm{m}^{3}$ for 
Manganese. The high concentration of $\mathrm{PM}_{10}, \mathrm{~Pb}$, $\mathrm{Zn}, \mathrm{Cd}$ and $\mathrm{Mn}$ in Sandoub area may be attributed to the nearby industrial emissions and high traffic density. Therefore, efforts should be taken to control the atmospheric pollution in order to protect humans from hazardous health effects of these potentially toxic pollutants.

\section{References}

Abu-Allaban M, Lowenthal D H, Gertler A W and Labib M (2007): Sources of PM10 and PM2.5 in Cairo's ambient air. Environment Monitoring Assessment. 133(1-3), 417-425.

Awan M A, Ahmed S H, Aslam M R and Qazi I A. (2011): Determination of Total Suspended Particulate Matter and Heavy Metals in Ambient Air of Four Cities of Pakistan. Iran J Energy Environ, 2, 128-32.

Awan M A, Ahmed H S, Aslam M R, Qazi I A and Baig M A (2013): Determination of heavy metals in ambient air particulate matter using laserinduced breakdown spectroscopy. Arab J Sci Eng. $38,1655-1661$.

Cheng K, Tian H Z, Dunhua Z and Huang Z (2014): Atmospheric emission inventory of cadmium from anthropogenic sources. Int. J. Environ. Sci. Technol. 11, 605-616.

Das R, Bahareh K, Bijayen S, Subhajit D, Pradip KS, Richard D and Webster XW, 2015. Trace element composition of PM2.5 and PM10 from Kolkata e a heavily polluted Indian metropolis. Atmos. Pollut. Res., 6, 742-750.

EEAA (1995): Egyptian Environmental Affairs Agency."Law No. 4, 1994: Promulgating the environmental law and its executive regulation". Egypt

El-Fadel M and Massoud M (2000): particulate matter in urban areas, health -based economic assessment. Sci. Total Environ, 257 (2-3), 133-146.

Engelstaedtera S, Tegenb $\mathrm{I}$ and Washingtona $\mathrm{R}$ (2006): North African dust emissions and transport. Earth Sci Rev, 79 (1-2), 73-100.

Ercan Ö and Dinçer F (2016): Atmospheric concentrations of $\mathrm{PCDD} / \mathrm{Fs}$, PAHs, and metals in the vicinity of a cement plant in Istanbul. Air Quality Atmospheric Health, 9, 159-172.

Estrellan C R and Iino F (2010): Toxic emissions from open burning. Chemosphere, 80,193-207.

Fang G, Chiang H, Chen Y C, Xiao Y F, Wu C M and Kuo Y C (2015): A measurement of summertime dry deposition of ambient air particulates and associated metallic pollutants in Central Taiwan. Environmental Geochemistry and Health, 37, 233249.
Gajghate D G, Pipalatkar P and Khaparde V V (2012): Atmospheric Concentration of Trace Elements, Dry Deposition Fluxes and Source Apportionment Study in Mumbai. Licensee in Tech, 7, 131-142.

Lodge J P and Editor J R (1998): Methods of Air Sampling and Analysis. 3rd ed., CRC Press LLC, Lewis Publishers, New York.

López J M, Callén M S, Murillo R, García T, Navarro M V, de la Cruz M T and Mastral A M (2005): Levels of selected metals in ambient air PM10 in an urban site of Zaragoza (Spain). Environmental Research, 99, 58-67.

Lowenthal D H, Gertler A W and Labib M W (2014): Particulate matter source apportionment in Cairo: recent measurements and comparison with previous studies. Int. J. Environ. Sci. Technol. 11:657-670.

Mao I, Lin C, Lin C, Chen Y, Sung F and Chen M (2009): Exposure of acid aerosol for schoolchildren in metropolitan Taipei. Atmospheric Environment, 43, 5622-5629.

Mobarakeh A S, Nabavi B F, Nikaeen M, Amin M M, Hassanzadeh A and Nadafi K (2015): Assessment of suspended particulate matters and their heavy metal content in the ambient air of Mobarakeh city, Isfahan, Iran. International Journal of Environmental Health Engineering, 3, 1-5.

Nasralla M M (2001): Greater Cairo air quality profile. A Report for EEPP (EEAA).

Pal R M, Gupta A and Tripathi A (2014): Assessment of heavy metals in suspended particulate matter in Moradabad, India. Journal of Environmental Biology, 35, 357-361.

Padoan E, Malandrino M, Giacomino A, Grosa M M, Lollobrigida F, Martini S and Abollino O (2016): Spatial distribution and potential sources of trace elements in PM10 monitored in urban and rural sites of Piedmont Region. Chemosphere145, 495507.

Police S, Sahu S K and Gauri G P (2016): Chemical characterization of atmospheric particulate matter and their source apportionment at an emerging industrial coastal city, Visakhapatnam, India. Atmospheric Pollution Research, 7, 725-733.

Quiterio S L, da Silva C R, Arbilla G and Escaleira V (2004). Metals in airborne particulate matter in the industrial district of Santa Cruz, Rio de Janeiro, in an annual period. Atmospheric Environment, 38, 321-331.

Ramadan Z, Song X H and Hopke P K (2000): Identification of sources of phoenix aerosol by positive matrix factorization. J. Air Waste Manage. 50, 1308-1320.

Salam A, Hossain T, Siddique M N, Shafiqul Alam A M. (2008): Characteristics of atmospheric trace 
gases, particulate matter, and heavy metal pollution in Dhaka, Bangladesh. Air Qual Atmos Health, 1, 101-9.

Shah M H, Shaheen N and Nazir R (2012): Assessment of the trace elements level in urban atmospheric particulate matter and source apportionment in Islamabad, Pakistan. Atmospheric Pollution Research, 3, 39-45.

Talebi S M and Abedi H (2004): Concentration of heavy metals in the atmosphere of the city of Isfahan, Pollution. Res., 23 (2) 211-214.

USEPA (2012): Air Quality Criteria for Particulate Matter. Vol. 1-3, Office of Research and Development, Washington DC (EPA Report No.EPA/001a-c).
Voutsa D, Samara C, Kouimtzis Th, Ochsenkühn K (2002): Elemental composition of airborne particulate matter in the multi-impacted urban area of Thessaloniki, Greece. Atmospheric Environment, 36, 4453-4462.

Weckwerth G (2001): Verification of traffic emitted aerosol components in the ambient air of Cologne (Germany). Atmospheric Environment 35, 55255536.

Zakey A S, Abdel-Wahab M M, Pettersson J B C, Gatari M J and Hallquist M (2008): Seasonal and spatial variation of atmospheric particulate matter in a developing megacity, the Greater Cairo, Egypt. Atmosfera 21(2):171-189.

\section{الملخص العربي}

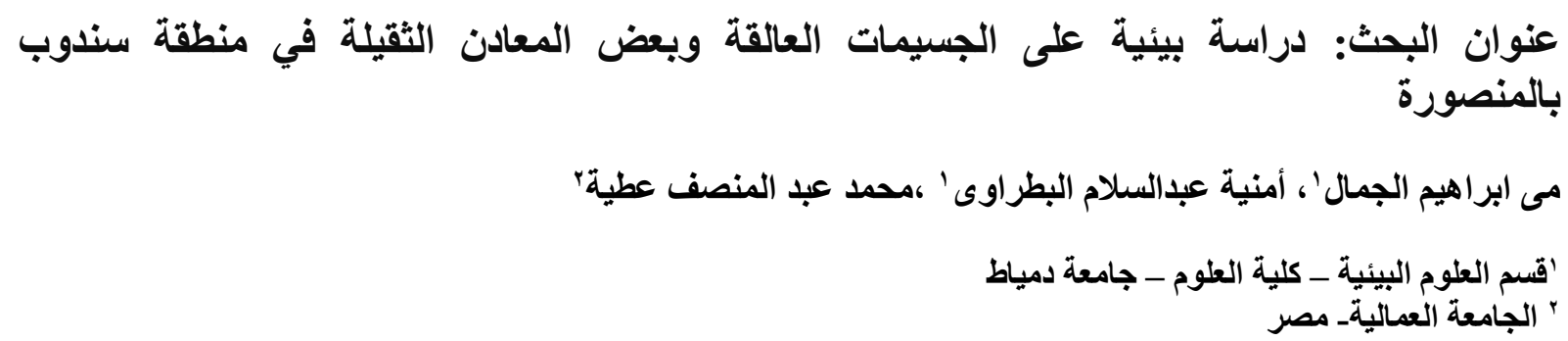

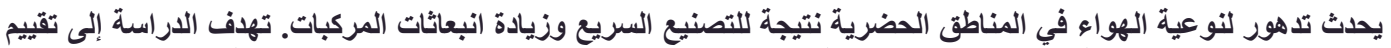

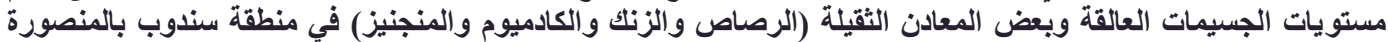

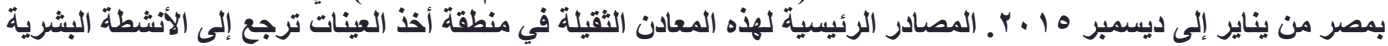

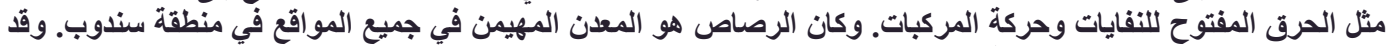

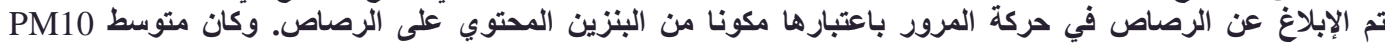

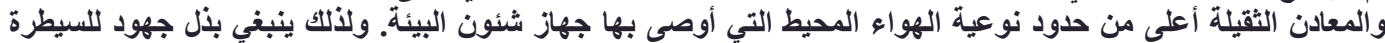

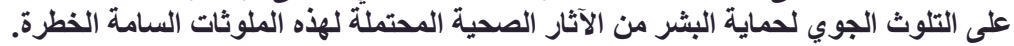

